\section{P-188＼cjkstart抗菌ペプチドが誘起する脂質膜中のポア形成のメカニズムー理諭 的解析}

Mechanism of Subcritical Pore Formation in Charged Lipid Vesicles Induced by Antimicrobial Peptides

Victor Levadny (1), Yukihiro Tamba (2), Masahito Yamazaki (2) ((1) Shizuoka University Russian Acadmy of Science: (2) Shizuoka University)

Antimicrobial peptides induce pore formation in lipid membrane. It is generally recognized that this pore formation is the key process in antimicrobial activity of these peptides. The pores with radius less than a certain critical value close quickly. The behavior of such subcritical pores determines the lifetime of intact lipid vesicles, from which no leakage of fluorescent probes occurs. Using the example of antimicrobial peptide magainin 2 -induced pore formation, we analyzed the behavior of the subcritical pores in giant unilamellar lipid vesicles (GUV). We assume a following scenario of GUV reaction on the antimicrobial peptides effect. The megainin 2 molecules adsorbed in the external monolayer of a GUV increase the total area of this monolayer by $\Delta S_{\text {tot }}$ but do not change monolayer mechanical state. Owing to the interplay between hydrophobic and hydrophilic interaction in inner monolayer its area increases also by the same value as $\Delta S_{\text {tor }}$. But in contrast to the external monolayer the non-zero internal tension arises in the inner one. The theory to determine variations of the internal tension in each monolayer due to the pore formation was developed. Making use of the opposing forces model of bilayer state we determined the tension in monolayer and the energy of the pore. Based on the developed theory we analyzed the mean lifetime of intact GUV in the presence of magainin 2 . The lifetimes under various conditions were determined in a framework of the Mean First Passage Time theory, which agreed well with experimental data.

\section{P-189 エタノールインジェクション法を利用したリポソーム融合}

Liposome fusion induced by charged lipids incorporated in the preformed liposomes using the ethanol injection method

Takeshi Sunami (1), Filippo Caschera (2), Yuki Morita (3), Kazuya Nishimura (3), Taro Toyota (4), Martin Hanczyc (2), Tomoaki Matsuura (3), Hiroaki Suzuki (3), Tetsuya Yomo (5) ((1) ERATO, JST: (2) University of Southern Denmark: (3) Osaka University: (4) Chiba University: (5) Osaka University; ERATO, JST)

Liposomes have long been used as possible compartments for artificial cells, and it has been shown that liposomes can sustain various types of biochemical reactions. To enable successive reaction in liposomes, we are studying liposome fusion as a method of supplying substrate molecules. We developed a new method to induce liposome fusion, which was detected by the fluorescenceactivated cell sorter (FACS). We utilized the ethanol injection method to introduce oppositely charged phospholipids into the membrane of preformed liposomes. We used an assay based on three fluorescent markers, R-phycoerythrin (R-PE), transferrin alexa 647 (TA) and calcein to detect liposome hemi-fusion (adhering) and fusion (mixing of two inner solutions) using FACS. The assay involves encapsulating R-PE in one set of liposomes and TA in the other set. When hemi-fusion occurs, the liposome emits both PE and TA fluorescence. For detection of fusion, the reporter system that emits fluorescence when two internal contents are mixed is necessary. Thus, we encapsulated the nonfluorescent $\mathrm{Co} 2+$ complex of calcein in one set of liposomes and EDTA in the other set. When fusion occurs, EDTA chelates Co2t, releasing calcein which emits intense green fluorescence. In this assay, we detected liposome hemi-fusion and fusion signal by mixing two populations of liposomes with oppositely charged membranes. Emergence of green fluorescence from calcein in liposomes was also confirmed under a microscopy. This liposome fusion method may be useful as a method of substrate supply.

\section{P-190＼cjkstart高頻度に分裂するベシクル自己複製系の構築とマイクロチャンバ 一を用いたその形態変化ダイナミクス計測 \\ Constructing highly self-reproducible giant vesicles and} measurement of the morphological dynamics in microchambers

Takuya Tomita (1), Tadashi Sugawara (3), Yuichi Wakamoto (2) ((I) Department of Basic Science, Graduate School of Arts and Sciences, The University of Tokyo: (2) Research Center for Complex Systems Biology, The University of Tokyo: (3) Department of Basic Science, Graduate School of Arts and Sciences, The University of Tokyo; Research Center for Complex Systems Biology, The University of Tokyo)

Self-reproduction of cells relies on the interplay of diverse sophisticated molecular machineries. The sophistication and diversity acquired through the evolution, however, hinder the clarification of the general principles underlying the phenomenon by analyzing the actual organisms. An alternative is to construct pseudo-cells; simple artificial chemical systems may be tractable both experimentally and theoretically. A giant vesicle (GV) system that exhibits selfreproduction is reported by Takakura et al.[1]. In this system, the membrane precursor molecule ("nutrient") supplied externally is transformed into the membrane molecule by the catalyst buried in the membrane of GV. The reaction induces morphological changes and division to new GVs. Despite its attractiveness, two technical issues should be resolved: 1) The low frequencies of morphological changes and division, and 2) Difficulty of statistical analysis due to the inability of tracking many GVs in solution. For the first issue, we newly designed and synthesized another type of membrane molecules that are structurally similar, but should induce the instability of the membrane. We find that adding the molecules to the system causes high frequent morphological changes to the GVs. For the second issue, we plan to entrap the GVs in microchambers, thereby restrict the movement of each GV within a small area. With this setup, it should be possible to track the morphological changes of many individual GVs simultaneously. [1] Langmuir, 20, 3832-4 (2004).

\section{P-191ＫcsA チャネルの開閉に伴う構造変化}

Rearrangements in the KcsA cytoplasmic domain underlie its gating

Minako Hirano (1), Yuko Takeuchi (1), Takaaki Aoki (1), Toshio Yanagida (1), Toru Ide (1) ((I) Graduate School of Frontier Biosciences, Osaka University)

The bacterial potassium channel KcsA is regulated by intracellular protons, which allows the channel to open at $\mathrm{pH}<5.5$. A change to acidic $\mathrm{pH}$ should lead to channel opening by inducing structural rearrangements within the channel. However, the overall gating mechanism, especially the contribution of the cytoplasmic domain, remains unsolved. To detect the conformational changes that accompany gating, macroscopic fluorescence intensities of several labeled mutants were measured under activated $(\mathrm{pH} 4)$ and inactivated $(\mathrm{pH} 7)$ conditions. Some mutants labeled at the cytoplasmic domain showed large fluorescence intensity differences between $\mathrm{pH} 4$ and $\mathrm{pH} 7$. Thus, these regions likely take different conformations for the open and closed states and dynamically change during gating. Therefore, this region might be important for the gating of the channel in response to $\mathrm{pH}$.

Next, to investigate the role of the cytoplasmic domain on gating, we made mutants that lacked the last residues $(\Delta 120-160, \Delta 125-160, \Delta 135-160$ and $\Delta$ 145-160). And we are measuring their activities under several conditions.

The results of the activities are shown, and the roles of the regions on gating are discussed.

\section{P-192 OmpF ポリンの陽イオン透過シミュレーション}

Molecular dynamics simulation of cation permeation through OmpF porin

Yasuhiro Matsuura (1), Atsushi Suenaga (2), Tadashi Ando (1), Ichiro Yamato (1) ((1) Department of Biological Science and Technology, Tokyo University of Science: (2) Highperformance Mol Simul Team, Comput Sys Biol Res Group, Adv Comput Sci Dept, RIKEN Adv Sci Inst)

OmpF porin, which is one of the major components of the outer membrane proteins in Escherichia coli, facilitates transports of small molecules and ions across the outer membrane. The ion conductance of $\mathrm{OmpF}$ was investigated for the series of alkali metal ions by using planar lipid bilayer: They were in the order of $\mathrm{Li}+<\mathrm{Na}+<\mathrm{K}+<\mathrm{Rb}+\sim \mathrm{Cs}+$. Diffusion potential measurement indicated that $\mathrm{OmpF}$ channel showed size preference for smaller cations. Besides of these experiments, ion permeation through $\mathrm{OmpF}$ porin has been studied by computational mehod. We have shown that sodium ion bound to Asp113 at the constriction zone. To understand the detailed mechanism of ion permeation across OmpF channel, we started MD simulation of OmpF trimer in lipid bilayer, especially in the presence of an applied transmembrane potential. After equilibration, we put cations at fixed position near the entrance of the channel and we could observe the ion permeating according to the applied membrane potential. Lithium ion seemed to stay near Asp1 13 for longer time than Cesium ion, which corresponds well to the result of conductance measurements. We are going to simulate these cation permeation in the absence of membrane potential.

\section{P-193＼cjkstart不活性化しない変異体であるE71A を用いた KcsA カリウムチャ ネルの $\mathrm{pH}$ 依存性}

pH-dependent gating of KcsA potassium channel examined by using an"inactivation-free"mutant, E71A.

Yuka Matsuki (1), Masayuki Iwamoto (1), Hirofumi Shimizu (1), Shigetoshi Oiki (1) ((l) Department of Molecular Physiology and Biophysics, University of Fukui Faculty of Medical Sciences)

Potassium channels regulate ion conduction by means of two gates located in series along the ion permeation pore. The helix gate closes when the helix bundle is crossed at the cytoplasmic end, while the filter gate closes when the selectivity filter collapses. KcsA potassium channel is a pH-dependent channel and shows the following gating kinetics. When cytoplasmic face is exposed to acidic $\mathrm{pH}$, the helix gate opens (activation) and then the filter gate closes (inactivation)subsequently. At the steady state the open probability of the KcsA channel is very low because of the low open probability of the filter gate. In the present study we examined the $\mathrm{pH}$-dependence of the helix gate and its gating kinetics using an inactivation-free mutant, E71A. E71 is lacated at the selectivity filter and formation of the hygrogen bond with D80 stabilizes the inactivated structure. Thus, single-channel currents of E71A mutant should predominantly represent gating behavior of the helix gate. The E71A channel was reconstituted into the planar lipid bilayer membrane and the gating behavior was recorded in 